\title{
Meiobenthic gradients with special reference to Plathelminthes and Polychaeta in an estuarine salt marsh creek - a small-scale model for boreal tidal coasts?
}

\author{
Monika Hellwig-Armonies \& Werner Armonies \\ Biologische Anstalt Helgoland (Litoralstation); D-2282 List, FRG
}

\begin{abstract}
Environmental conditions in salt marsh creeks are intermediate between the open tidal coast and estuaries. A large salt marsh creek at the island of Sylt (North Sea) was studied in order to test whether its fauna is more similar to that of the open tidal coast or to that of estuaries. Because of a sandy bar at the seaward opening, the tidal range is only $10 \mathrm{~cm}$ in the creek, and the water level never drops below the level of the sand bar. Zoobenthos in the sandy bottom and on the sandy shores was studied at both ends and in the middle of the creek. Polychaeta and Plathelminthes were determined to species level. On an average, 2115 metazoans were found below $10 \mathrm{~cm}^{2}$ of surface area. At the seaward end of the creek, abundance and taxonomic composition are similar to that of the adjoining Wadden area. Nematoda are the dominant taxon, followed by Copepoda, Plathelminthes and Oligochaeta. Taxonomic composition is different at the landward end. Plathelminthes and Nematoda are most abundant followed by Copepoda. Both Oligochaeta and Polychaeta are scarce at these newly eroded sites. Plathelminth abundance at the landward end of the creek is exceptionally high $\left(770-935 \cdot 10 \mathrm{~cm}^{-2}\right)$. Contrary to what is generally found in estuaries, the species density of Plathelminthes shows a significant increase toward the land. The species composition of Polychaeta and Plathelminthes indicates that the sites below mean high tide level of the creek correspond to the adjacent eulittoral Wadden area while the fauna of the supralittoral sites of the creek is similar to the fauna of supralittoral tidal coasts. Typical sublittoral species did not occur in the salt marsh creek. Thus, salt marsh creeks may be regarded as a small-scale model for the tidal coast. In context with the results obtained, the definition of estuaries is discussed.
\end{abstract}

\section{INTRODUCTION}

An estuary is a partially enclosed coastal body of water which is either permanently or periodically open to the sea and within which there is a measurable variation of salinity due to the mixture of sea water with fresh water derived from land drainage (Day, 1980, 1981). Compared to the open tidal coast other environmental factors such as temperature may be more variable too. This affects the faunal composition. In general, the number of species is rather low, but individual abundances may be high. On the other hand, estuaries are less exposed to wave action, and food supply may be better than on tidal coasts because of river or salt marsh input (cf. Wolff, 1983 for a review).

The environmental conditions of larger salt marsh creeks are similar to those of estuaries. The seaward end of salt marsh creeks is dominated by marine factors, and limnic and terrestric factors become increasingly more important toward the land. At the same time, sea water interchange decreases and fresh water influx becomes more 
important. Temperature exhibits wider ranges landwards than at the seaward end. Water movement is generally weak.

In estuaries, the number of species generally decreases with increasing fresh water influence (Riemann, 1966; Sanders, 1968; Boesch, 1977; Bouwman, 1981; Wolff, 1983), whereas species density of small zoobenthos does not remarkably change between sublittoral and supralittoral zones of the tidal coast (Armonies \& Hellwig-Armonies, 1987). On the island of Sylt in the northern Wadden Sea, a larger salt marsh creek was investigated in order to test whether its fauna is more similar to that of estuaries or to that of tidal coasts.

\section{MATERIAL AND METHODS}

\section{Sample sites}

During westerly gales, the supralittoral salt marshes on the island of Sylt are flooded. Sea water enters the marsh at all sites where the level of the seaward salt marsh border is lower than the actual high tide level. After the storm, the sea water returns to the sea, flowing preferentially through the small depressions and grooves of the salt marsh. Erosion of these grooves forms salt marsh creeks. Initially, the creek is only wet when a storm tide has preceeded. However, by regressive erosion the bottom level will become deeper after every storm tide. When the ground water level is reached the creek is large enough to be partially filled with water throughout the year. A salt marsh creek of this kind was studied.

The creek is located in a salt marsh approximately $300 \times 1000 \mathrm{~m}$ in the northern part of the island of Sylt (North Sea) adjacent to the Königshafen Wadden area (Fig. 1). The creek is about $600 \mathrm{~m}$ long. At the seaward end it is about $12 \mathrm{~m}$ wide and it narrows landwards to less than $1 \mathrm{~m}$. The surrounding salt marsh is intensively grazed by sheep. Because of the geological situation, the bottom of the salt marsh creek consists of relatively coarse sand (median diameter of sand grains 300 to $400 \mu \mathrm{m}$ ). Sorting is quite heterogenous. The percentage of fine material (silt, detrital particles) is low at the seaward side $(<1 \%)$ and tends to increase landwards. However, it is much influenced by small-scale currents, and during storm tides the silt content may be highly reduced all over the creek.

The minimum water level (i.e. the water level reached during low tide) is about $60 \mathrm{~cm}$ on the seaward side and decreases to zero in landward direction. A sand bar between the seaward end of the salt marsh creek and the adjoining Wadden area prevents a further sea water outflow beyond this level. Therefore, an average high tide increases the water level of the creek by only $10 \mathrm{~cm}$ and the "eulittoral zone" is rather narrow. The "supralittoral" zone reaches up to $35 \mathrm{~cm}$ above mean high tide level (MHTL), and the surrounding sait marsh is about 40 to $50 \mathrm{~cm}$ above MHTL. Near bends of the creek, currents engender sandy shores. Mostly, however, the creek borders directly on the salt marsh. Here, the shore is an almost vertical declivity, or it has partly slipped due to erosion. These salt marsh shores were excluded from this study, and only the sandy sites were investigated.

On October 13th 1986, samples were collected at the seaward end of the salt marsh creek, in the middle of the creek and at its landward end. There were 7 sampling stations at the seaward end, arranged according to the height above MHTL $(-50 \mathrm{~cm},-30 \mathrm{~cm}$, 
$\left.-10 \mathrm{~cm}, 0,+10 \mathrm{~cm}_{\mathrm{r}}+20 \mathrm{~cm},+30 \mathrm{~cm}\right)$. The sandy shore was not so high in the middle of the creek, and the $+30 \mathrm{~cm}$ station had to be omitted. Because of the limited vertical extension of the shore at the landward end, there were only 3 stations $(-10 \mathrm{~cm}, 0$, and $+10 \mathrm{~cm}$ above MHTL). Salinity varied between $31 \%$ at the seaward end and $26 \%$ at the landward end. Water temperature was 12 to $13^{\circ} \mathrm{C}$.

\section{Sampling and extraction}

10 replicates were collected at each station using $1-\mathrm{cm}^{2}$ glass tubes. Vertically, the samples included all of the oxic sediment layer plus the uppermost centimetres of anoxic

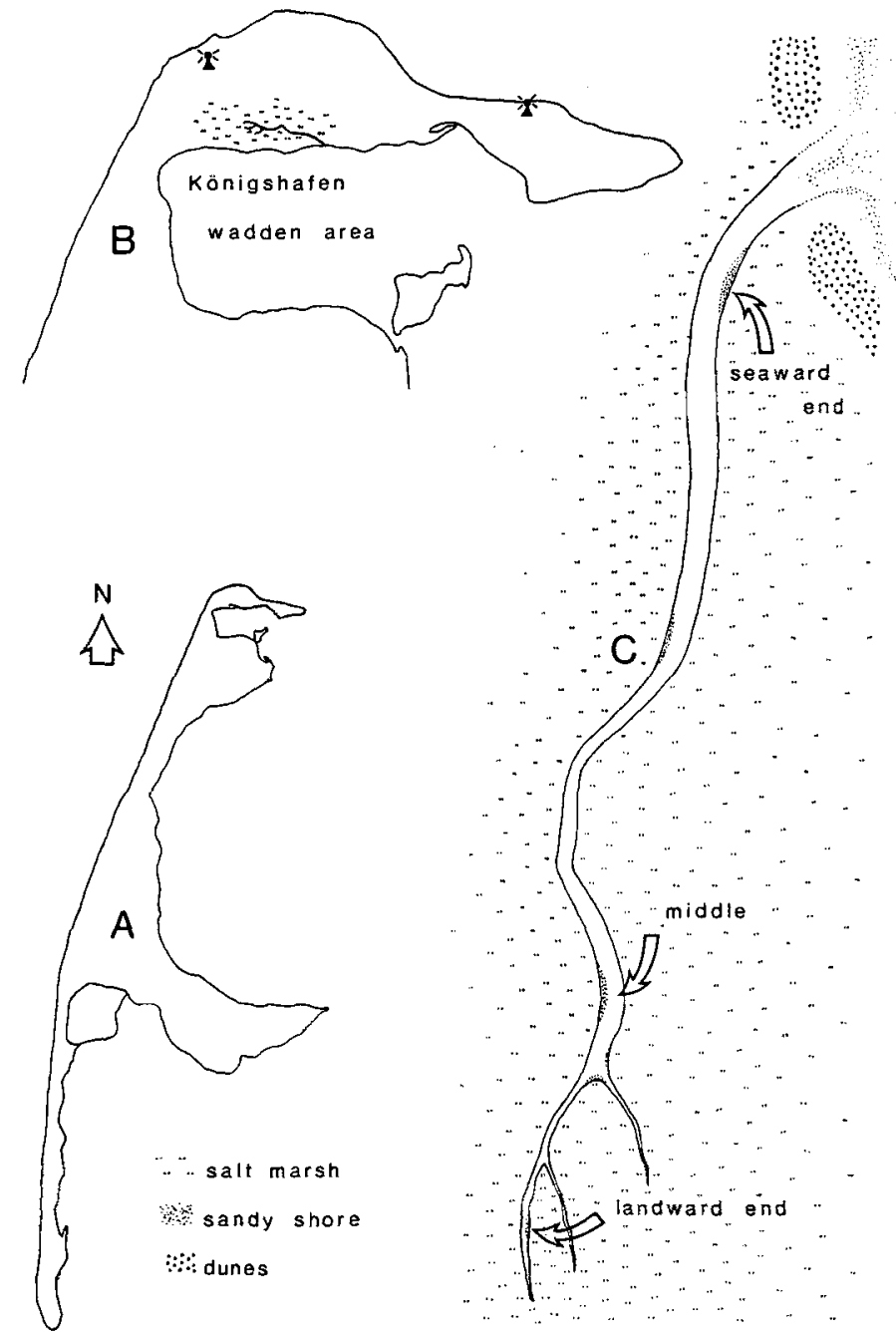

Fig. 1. A. The island of Sylt. B. Northern part of the island with the Königshafen Wadden area. The studied salt marsh creek with the surrounding salt marsh is indicated. C.The salt marsh creek with sampled sections 
sediment. Above the water line, sampling was restricted to $10 \mathrm{~cm}$ below ground water level. The sediment column was vertically divided into $10 \mathrm{~cm}$ layers if the sampled depth exceeded $10 \mathrm{~cm}$.

Meiofauna was extracted using a shaking-decantation procedure. Samples were washed into a beaker $\left(600 \mathrm{~cm}^{3}\right.$ ). Filtered sea water was added (about $50 \mathrm{~cm}^{3}$ ) and the beaker was gently shaken. Then the supernatant was decanted into a second beaker. Intensifying shaking and rotating, this procedure was repeated about 10 times. The final 2 washes were carried out using fresh water instead of sea water (application time $1 \mathrm{~min}$ ). This causes animals formerly attached to sand grains to lose hold of their anchors; they can, thus, be extracted easily. No wounded or damaged animals were observed after this treatment.

The gathered supernatants were concentrated by sieving through $250-\mu \mathrm{m}$ and $40-\mu \mathrm{m}$ meshes. The residues were transferred into Petri dishes. From these dishes the fauna was sorted and all major taxa counted. Polychaeta and Plathelminthes were determined to species level. Other taxa were treated as groups. In sheltered and semi-exposed sand, the above method yields quantitative extraction of all metazoan fauna (Hellwig, 1987). Only very small animals passing the $40-\mu \mathrm{m}$ meshes are lost.

\section{Statistical analyses}

Abundance of most taxa shows significant deviation from randomness (significant deviation of the variance-to-mean ratio from the appropriate reference of a chi-square table: Gage \& Geekie, 1973), and aggregation is the rule. The means and standard deviations given in Table 1 are therefore only approximations. Accordingly, non-parametrical tests are an adequate means of statistical evaluation. We used the non-parametrical U-test (Wilcoxon et al. in Sachs, 1984).

Faunal affinities between sites are expressed with Renkonen's index ( $R=\Sigma$ pi, with pi being the proportion of individuals in the site where species $i$ is less abundant) and Sørensen's index [S $=2 j /(a+b)$, with $j$ being the joint number of species, and $a$ and $b$ are the number of species in both sites]. While $S$ expresses the fraction of common species, $R$ evaluates the significance of every species and gives the affinity in terms of dominants rather than species.

Species diversity is characterized by Shannon's entropy $\left(\mathrm{H}^{\prime}=-\Sigma \mathrm{pi} \times \ln\right.$ pi, where pi is the proportion of the $i$-th species, $i=1,2,3, \ldots, S$ ), and by a modification of Simpson's measure of concentration ( $\mathrm{D}=1-\Sigma \mathrm{pi}^{2}$, with pi as above).

\section{RESULTS}

\section{Abundance and taxonomic composition}

On an overall average, 2115 metazoans were found per $10 \mathrm{~cm}^{2}$ of surface area. Abundance is close to this mean at the seaward end of the salt marsh creek. In the middle of the creek, abundance is significantly lower, and at the landward end it is significantly higher (Table 1). However, considering only sites above mean high tide level there are no significant differences, and the above tendency is only due to the 'sublittoral' sites. In the middle of the creek, abundance is significantly higher above MHTL than below. The opposite is true at the ends of the creek (Table 1). 


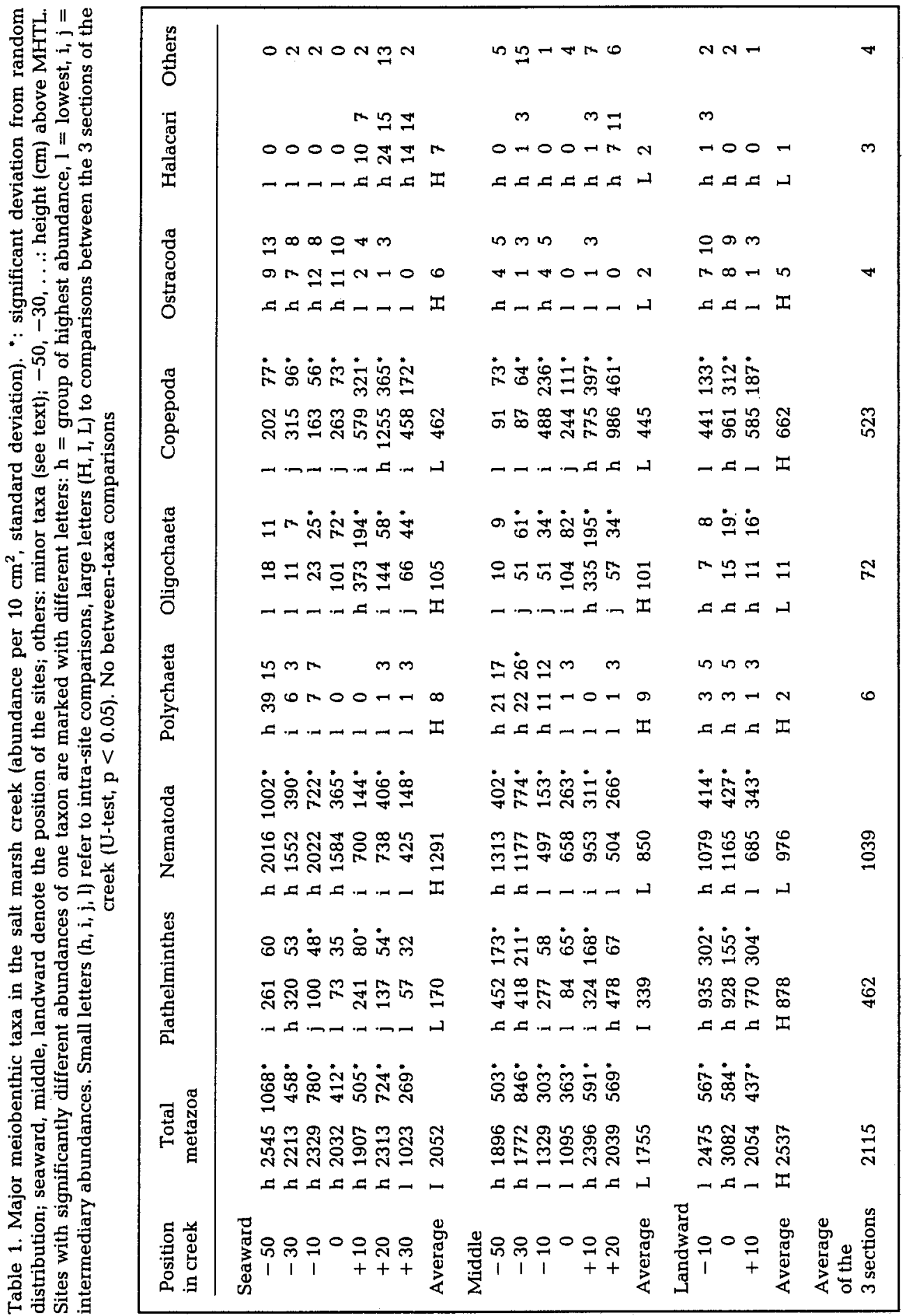


At the seaward end of the creek, metazoan abundance does not significantly differ between $-50 \mathrm{~cm}$ and $+20 \mathrm{~cm}$. Only the uppermost $(+30 \mathrm{~cm})$ site shows a significant decrease. In the middle of the creek, the significantly lower abundance of metazoans in the 'sublittoral' compared to the 'supralittoral' sites is caused by low abundance at -10 and $0 \mathrm{~cm}$, while there is no significant difference between the other sites. The highest total of metazoan abundance was found at the water line of the landward end of the salt marsh creek $\left(>3000 \cdot 10 \mathrm{~cm}^{-2}\right)$.

Nematoda reach highest abundances in the lowermost sites of every section of the creek with highest values at the seaward side. There are no significant differences in number between the 'supralittoral' sites (Table 1). Copepoda are more abundant at sites above MHTL. Abundance is highest at the seaward end at $20 \mathrm{~cm}$ above MHTL. In the middle the +10 and $+20 \mathrm{~cm}$ sites are equally occupied, and at the landward end highest abundance is found at the water edge. The preferred height level changes obviously from $+20 \mathrm{~cm}$ to $0 \mathrm{~cm}$ in a landward direction.

The abundance of Plathelminthes shows no trends at the seaward side, and there are no significant differences between the landward sites (Table 1). In the middle of the creek, abundance is lowest at the water edge, and increases towards both higher and deeper sites. A similar pattern is also observed in the copepod abundance of these sites. Presumably, this is an effect of small-scale currents or wind driven waves. In the course of the creek, the plathelminth abundance strongly increases toward the land, up to an average of nearly $900 \cdot 10 \mathrm{~cm}^{-2}$. At $10 \mathrm{~cm}$ above MHTL they are the dominant taxon (Table 1).

Oligochaeta reach highest abundances just above MHTL. Abundance does not significantly differ between the seaward side and the middle of the creek, but it is very low at the landward end. Polychaeta and Ostracoda are both most abundant below water level, and Halacarida tend to be more abundant above water level (Table 1).

Besides these major taxa, Gastrotricha (Macrodasyoida), Tardigrada (Batillipes mirus), Protohydra leuckarti, Gnathostomula cf. paradoxa, and the macrofaunal species Hydrobia ulvae, Macoma balthica, and Corophium sp. occurred ("others" in Table 1). Locally more abundant were Gastrotricha above MHTL at the seaward end, Tardigrada above MHTL and Protohydra below MHTL at the middle of the salt marsh creek.

On the seaward side of the creek, Nematoda dominate at the sites below MHTL, and Copepoda above. In the course of the creek, the proportion of Nematoda decreases landwards, and the share of Plathelminthes increases. On an average of all sites the proportion of Copepoda is similar all over the creek. Oligochaeta play a major role only at the seaward end and in the middle of the salt marsh creek.

\section{Faunal affinities in Polychaeta}

A total of 10 polychaete species is recorded (Table 2). Polychaete abundance and species number show the same tendency. There are no significant differences between the seaward end and the middle of the creek, but Polychaeta are scarce at the landward end. The 'sublittoral' is richest in individuals as well as species, and diversity is highest there (Table 1, 2, 3).

The highest faunal similarity of all sites is found between the seaward end and the middle of the creek ( 4 species in common), and lowest between the seaward and 


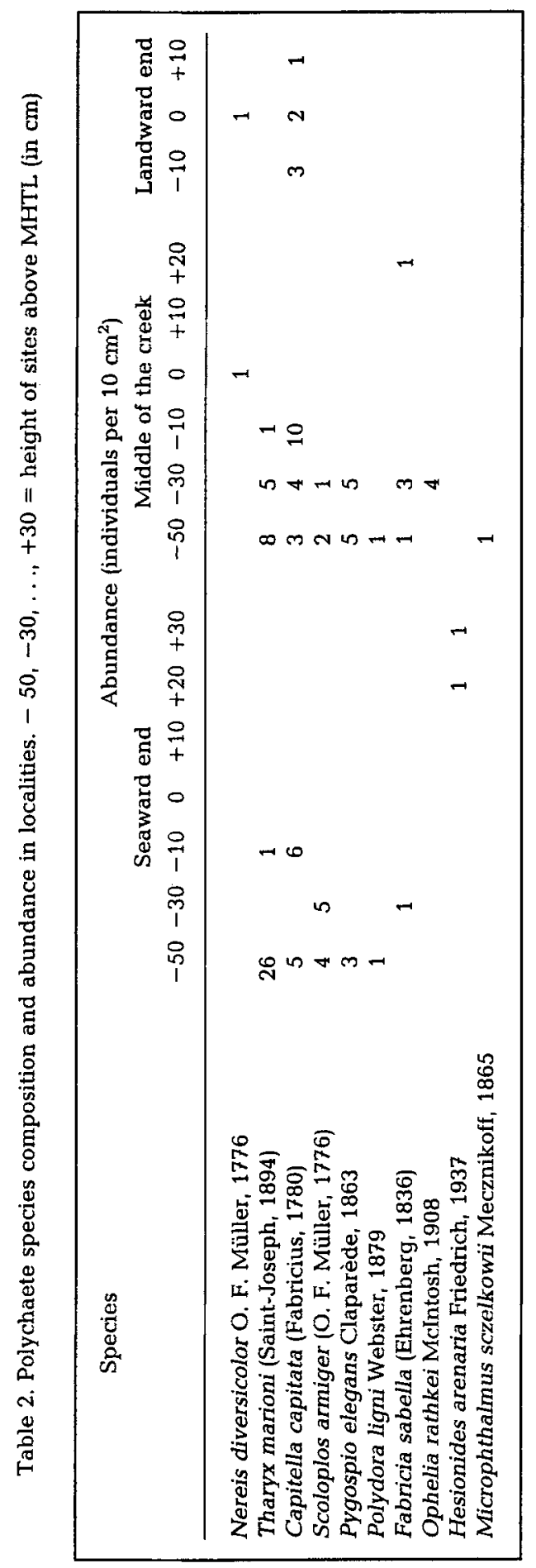


Table 3. Species richness and diversity of Polychaeta and Plathelminthes. Computed on the combined values of the respective sites (not averages)

\begin{tabular}{|c|c|c|c|c|c|c|}
\hline & \multicolumn{3}{|c|}{ Polychaeta } & \multicolumn{3}{|c|}{ Plathelminthes } \\
\hline & species & $\mathrm{H}^{\prime}$ & $\mathrm{D}$ & species & $\mathrm{H}^{\prime}$ & $\mathrm{D}$ \\
\hline \multicolumn{7}{|l|}{ Seaward end } \\
\hline MHTL and below & 6 & 1.289 & .652 & 39 & 2.193 & .750 \\
\hline Above MHTL & 1 & 0 & 0 & 38 & 2.783 & .887 \\
\hline Total & 7 & 1.400 & .676 & 67 & 2.981 & .883 \\
\hline \multicolumn{7}{|l|}{ Middle of creek } \\
\hline MHTL and below & 9 & 1.745 & .776 & 35 & 2.549 & .870 \\
\hline Above MHTL & 1 & 0 & 0 & 25 & 2.011 & .776 \\
\hline Total & 9 & 1.758 & .781 & 46 & 2.855 & .913 \\
\hline \multicolumn{7}{|l|}{ Landward end } \\
\hline MHTL and below & 2 & .451 & .278 & 31 & 1.998 & .810 \\
\hline Above MHTL & 1 & 0 & 0 & 28 & 1.804 & .774 \\
\hline Total & 2 & .410 & .245 & 38 & 2.001 & .798 \\
\hline \multicolumn{7}{|l|}{ Overall totals } \\
\hline MHTL and below & 9 & 1.625 & .741 & 52 & 2.515 & .864 \\
\hline Above MHTL & 3 & 1.040 & .625 & 63 & 2.802 & .892 \\
\hline Total of creek & 10 & 1.694 & .753 & 83 & 2.906 & .904 \\
\hline
\end{tabular}

Table 4. Faunal similarity of Polychaeta and Plathelminthes. Re $=$ Renkonen's index; Sø $=$ Sørensen's index; around MHTL $=-10$ to $+10 \mathrm{~cm}$

\begin{tabular}{|c|c|c|c|c|c|c|}
\hline & \multicolumn{2}{|c|}{ Seaward - middle } & \multicolumn{2}{|c|}{ Middle - landward } & \multicolumn{2}{|c|}{ Seaward - landward } \\
\hline & $\operatorname{Re}$ & $\mathrm{S} \emptyset$ & $\mathrm{Re}$ & So & $\operatorname{Re}$ & $\mathrm{S} ø$ \\
\hline \multicolumn{7}{|l|}{ Polychaeta } \\
\hline All sites & .610 & .750 & .353 & .363 & .204 & .222 \\
\hline MHTL and below & .628 & .800 & .360 & .363 & .212 & .278 \\
\hline Above MHTL & 0 & 0 & 0 & 0 & 0 & 0 \\
\hline Around MHTL & .917 & .800 & .917 & .800 & .857 & .500 \\
\hline \multicolumn{7}{|l|}{ Plathelminthes } \\
\hline All sites & .539 & .673 & .361 & .643 & .289 & .495 \\
\hline MHTL and below & .580 & .757 & .457 & .697 & .372 & .629 \\
\hline Above MHTL & .451 & .508 & .087 & .415 & .096 & .242 \\
\hline Around MHTL & .486 & .555 & .235 & .600 & .207 & .410 \\
\hline
\end{tabular}

landward ends (no common species, Table 4). Polychaetes show a regular faunal gradient in the course of the creek. However, there is a very high faunal similarity between the sites around MHTL $(-10$ to $+10 \mathrm{~cm})$. Because of very low abundance and species numbers, the faunal similarity of 'supralittoral' sites is zero (Table 4). Thus, the differences in polychaete faunal similarity are only due to the sites deeper than $10 \mathrm{~cm}$ below MHTL. 


\section{Faunal affinities in Plathelminthes}

Plathelminthes are rich in species all over the salt marsh creek. A total of 83 species is recorded (Table 5). As is the case in individual abundances, the average species density per $10 \mathrm{~cm}^{2}$ is highest at the landward end. There are 20.3 species $\cdot 10 \mathrm{~cm}^{-2}$ at the seaward end, 20.0 in the middle, and $25.7 \cdot 10 \mathrm{~cm}^{-2}$ at the landward end. These differences are even more evident, when the sites between -10 and $+10 \mathrm{~cm}$ above MHTL are compared (i.e. the height level of the landward sites). At this level there were 18.7 species $\cdot 10 \mathrm{~cm}^{-2}$ on the seaward side and 18.0 in the middle of the creek.

The highest similarity of faunal composition is found between the seaward end and the middle of the creek (13 species in common), and similarity is lowest between the seaward and landward ends (Table 4 ). These 2 sites have only 3 species in common, and 4 species are common to the middle and landward side. Thus, as is the case in Polychaeta, Plathelminthes show a regular faunal gradient in the course of the creek, The average similarity is higher between the 'sublittoral' sites than between sites above MHTL (Sørensen's index, Table 4). Regarding Renkonen's index, the differences become more prominent because of different dominants. Unlike Polychaeta, the faunal similarity is not extraordinarily high around MHTL. Nevertheless, when comparing all sites the pattern of faunal similarity resembles that of Polychaeta.

The low faunal similarity of Polychaeta between the seaward and landward ends of the creek is due to low abundance and species numbers at the landward sites, which also causes low diversity $\mathrm{H}^{\prime}$ (Table 3 ). This is not the case in Plathelminthes. Diversity $\mathrm{H}^{\prime}$ decreases towards the landward end of the salt marsh creek because of the strong dominance of a few species, and not because of decreasing species richness (cf. Table 5).

From the totál of 83 plathelminth species, 23 occurred at all 3 stations. 26 species were restricted to the seaward end, 7 to the landward end, and only 2 to the middle of the creek. Pseudaphanostoma pelophilum (Acoela) was the most abundant species with up to 350 individuals per $10 \mathrm{~cm}^{2}$, followed by Pogaina suecica (Dalyellioida). This species was dominant in the middle and the seaward end of the creek, and $P$. pelophilum at the landward end (Table 5). Both species feed on diatoms.

\section{DISCUSSION}

Abundance and taxonomic composition compared to the tidal coast

Some weeks prior to this study, a network of sublittoral, eulittoral, and supralittoral sites was sampled near the island of Sylt, and the benthic fauna was evaluated (Armonies \& Hellwig-Armonies, 1987). Because of similar methods, and the short distances both in time and space between the sampling occasions, this study is well qualified to serve as a comparison. As concerns the sediment composition, the 'muddy sand' sites of the above study are most similar to the salt marsh creek. However, the supralittoral and eulittoral samples of Armonies \& Hellwig-Armonies (1987) reached further down into the anoxic sediment layer, and accordingly, a higher proportion of the taxa living there is to be expected. Above all, this concerns Nematoda and deep dwelling annelids. Conversely, most of Copepoda and Plathelminthes live in the oxic surface layer, and these taxa were not affected. 


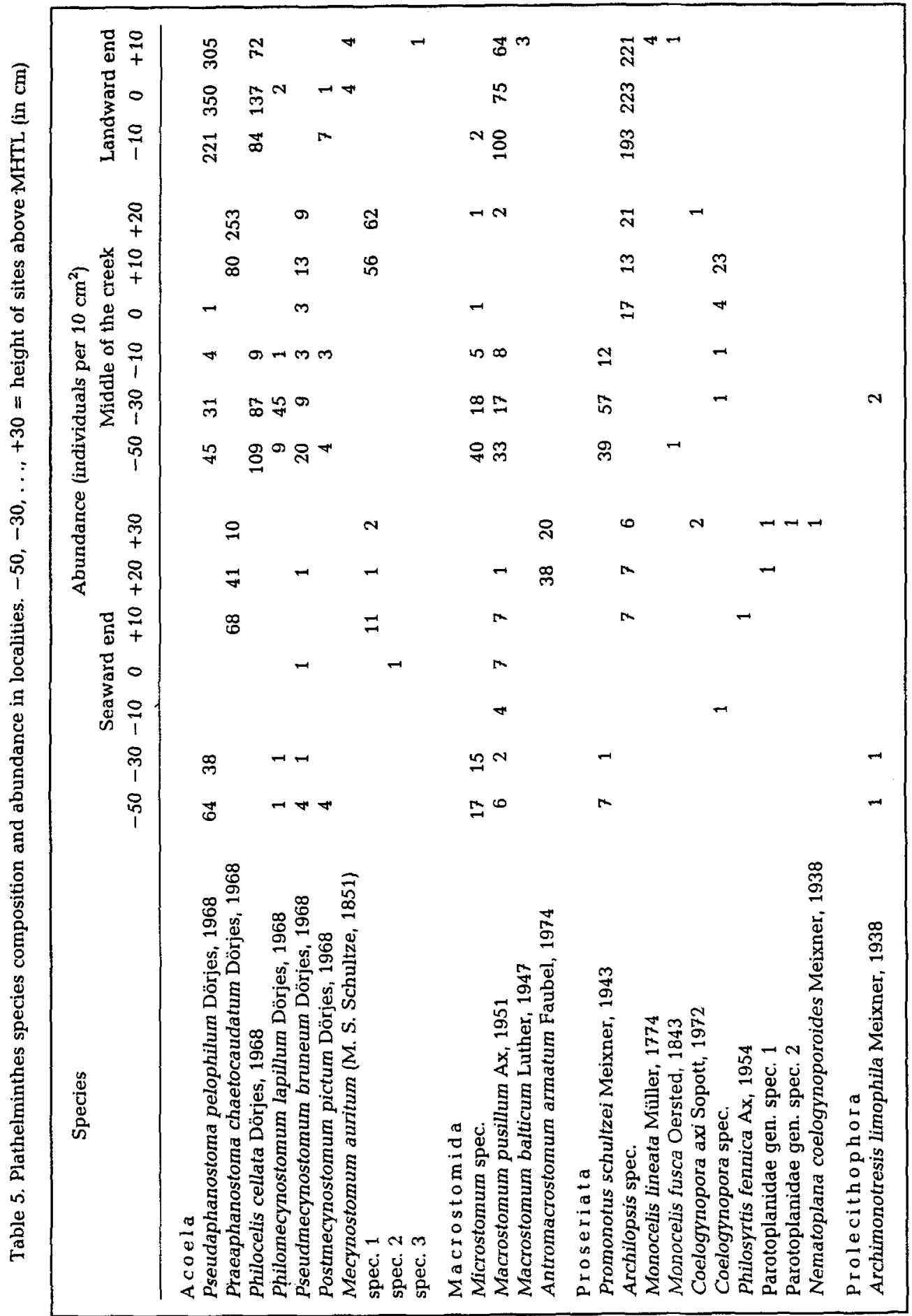




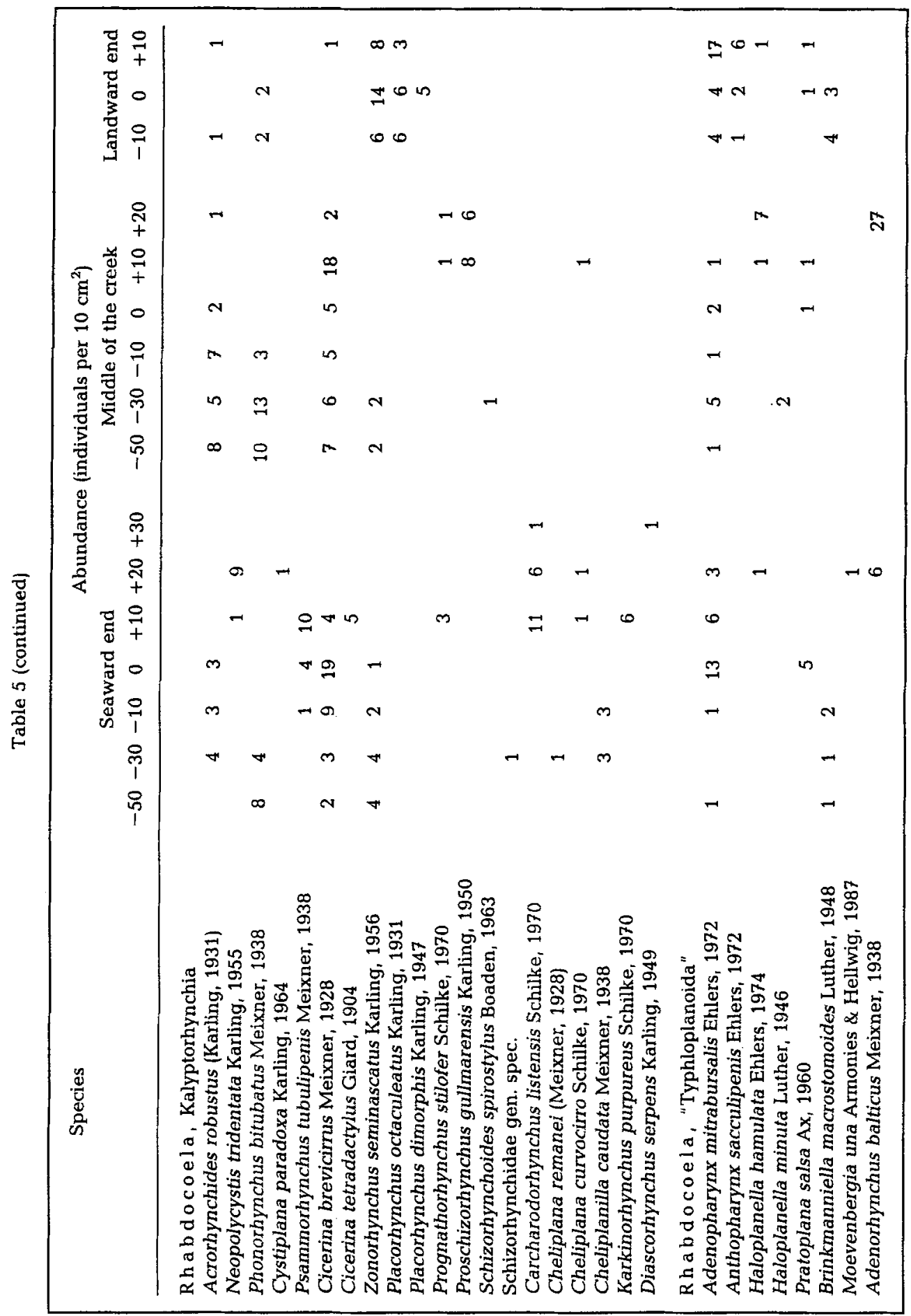




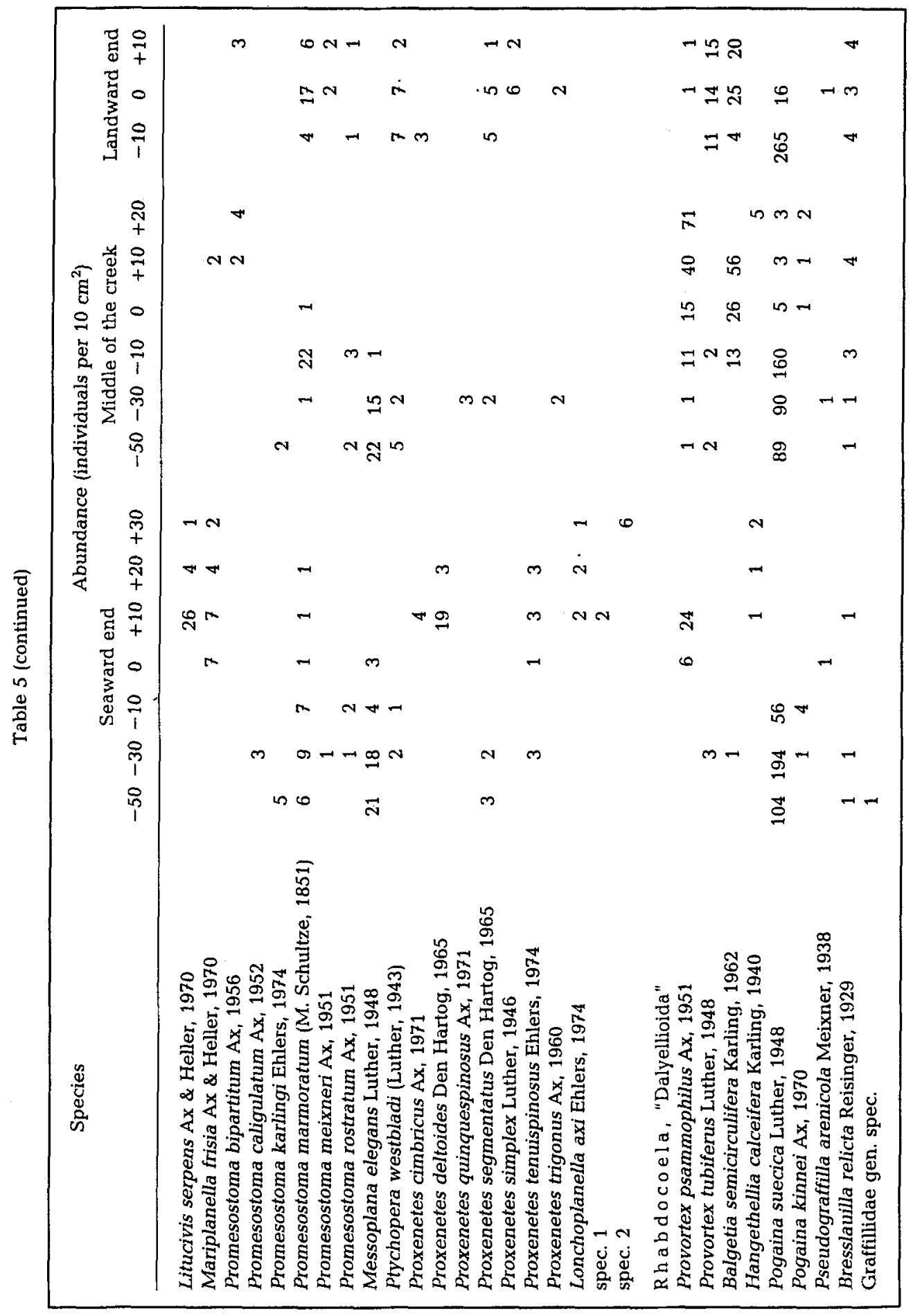


At the seaward end of the salt marsh creek, total zoobenthos abundance decreases from the 'sublittoral' sites toward the 'supralittoral'. This is mainly caused by the abundances of Nematoda which are the dominant taxon here. The same tendency was observed in the adjoining Wadden area. In contrast, in the middle of the creek, abundance of both total meiofauna and Nematoda is lowest in the 'eulittoral' (=MHTL). In the seaward as well as in the middle part of the creek, the number of Polychaeta strongly decreases from the 'sublittoral' towards the 'supralittoral', and oligochaete numbers increase. The same tendency was observed at the tidal coast. Abundance of Copepoda continuously increases towards the 'supralittoral' in both the seaward and middle part of the creek. At these sites, the distribution of Plathelminthes shows no general tendency but abundance is lowest in the 'eulittoral' (Table 1). In the adjoining Wadden area, distribution patterns of these taxa are just the opposite (Armonies \& Hellwig-Armonies, 1987).

At the landward end of the creek, most taxa show unique distribution patterns that clearly differ from both the tidal coast and the other sites of the salt marsh creek. Total meiofauna and Copepoda are most abundant in the 'eulittoral', while the abundance of Plathelminthes and Nematoda do not significantly differ between the 'sublittoral' and 'eulittoral' site, and abundance is lowest in the 'supralittoral'.

As was expected from the limited sampling depth, abundance of total zoobenthos, Nematoda, and of deep dwelling Polychaeta is lower in the salt marsh creek, whereas abundance of Copepoda is not significantly different. In the seaward and middle part of the creek, Oligochaeta are more abundant than in the Wadden Sea area, but their number is strongly diminished at the landward end of the creek.

The most striking difference between the salt marsh creek and the adjoining tidal coast is the significantly higher abundance of Plathelminthes in the creek. Their number continuously increases landwards where they are more abundant than Copepoda, and there is no significant difference between nematode and plathelminth abundances. In the 'supralittoral', Plathelminthes are the dominant metazoan taxon. At the same time, the proportion of both Polychaeta and Oligochaeta is unusually small. Possibly, annelids need longer to occupy the newly eroded ends of salt marsh creeks, and some plathelminth species benefit from their absence. The greater influence of terrestrial factors on the landward ends of salt marsh creeks is another possible cause for the differences in faunal composition.

The above indicates that the faunal similarity between the tidal coast and the salt marsh creek decreases from the seaward towards the landward parts. The seaward end of the creek is quite similar to the Wadden Sea, while the landward end has unique characters. The same tendency is observed when estuaries are compared to the tidal coast (e.g. Ax, 1956).

\section{Species richness and diversity of Polychaeta}

At the seaward sites of the salt marsh creek, 7 species of Polychaeta were found, and 9 in the middle section. Because of limited sampling depth, the polychaete fauna was not completely recorded. For instance, many funnels and casts generated by the lugworm Arenicola marina are seen all over the creek, but this species was not found in the samples. The small sample size ( $1 \mathrm{~cm}^{2}$ surface area, 10 replicates) is another reason why 
Polychaeta are not completely recorded. The small number of polychaete species at the landward end of the creek may also be caused by the limited vertical dimension of the 'sublittoral'. With these restrictions, the polychaete species richness is not significantly different from the shallow water sites of the tidal coast (cf. Armonies \& HellwigArmonies, 1987). However, diversity $\mathrm{H}^{\prime}$ is lower in the salt marsh creek. The limited sampling depth is again a possible cause, and the wider range of environmental factors is another. All polychaete species of the creek are also known from the adjacent tidal coast (Reise, 1985; Armonies \& Hellwig-Armonies, 1987).

\section{Species richness and diversity of Plathelminthes}

Plathelminthes are more specific in their environmental demands than Polychaeta (Armonies \& Hellwig-Armonies, 1987; Hellwig, 1987). They are richer in species in the salt marsh creek than in the adjoining Wadden area. This result is opposite to the situation often described from estuaries (Riemann, 1966; Day, 1981) where landward gradients of decreasing species richness are observed. Warwick \& Gee (1984) also found deviations from this rule (see below).

At the seaward end and in the middle of the creek, the lowest numbers of plathelminth species were found at MHTL. These low numbers are very similar to the average species richness in the adjoining Wadden area (Armonies \& Hellwig-Armonies, 1987). Because of wind driven waves, the amount of mud and detritus at the sediment surface is lowest at MHTL of the seaward and middle creek sections. Thus, the higher numbers of plathelminth species at the other sites of the creek is presumably due to the insignificance of wave action and the lack of stronger tidal currents. Mud accretion and high abundance of diatoms favours the plathelminth fauna. The landward end is the most sheltered part of the creek, and both individual and species numbers of Plathelminthes are highest there (Table 1,3). The percentage of diatom feeding individuals is signifanctly higher in the salt marsh creek than in the Wadden area investigated by Reise (1984), and it is similar to that found in an intertidal mud flat (Dittmann \& Reise, 1985).

At the seaward end of the creek, diversity $\mathrm{H}^{\prime}$ of Plathelminthes is very similar to the adjoining Wadden area but tends to decrease toward the land (Table 3 ). This decrease is caused by the stronger dominance of few species, not by low species numbers. Thus, species numbers and diversity $\mathrm{H}^{\prime}$ are not correlated. A similar situation was observed by Sanders (1968) when comparing the bivalve and polychaete components of soft-bottom marine faunas.

Most of the Plathelminthes inhabiting the creek are typical species of sheltered boreal tidal coast. Nearly all of the species that have been found below MHTL of the creek are also known from sheltered tidal flats, such as the dominant species in the creek, Pseudaphanostoma pelophilum and Pogaina suecica (Reise, 1984; Dittmann \& Reise, 1985; Hellwig, 1987). The next most abundant species Philocelis cellata is furthermore known to be characteristic for salt marsh creeks (Hellwig, 1987). Obviously, these species can exist without tidal conditions as well. Plathelminthes that were restricted to the sandy supralittoral sites of the creek seem to be restricted to the supralittoral in sheltered sandy beaches of the tidal coast, too (Hellwig, 1987). Some species of the seaward 'supralittoral' can also be found in more exposed beaches of the island of Sylt (Armonies \& HellwigArmonies, 1987). Plathelminthes from the surrounding salt marshes did not penetrate the 
creek. These species seem to be restricted to the brackish water conditions of salt marshes with strong salinity fluctuations (Armonies, 1986, 1987). Phonorhynchus bitubatus has not been found elsewhere in the German Bight. This species might be a special inhabitant of salt marsh creeks.

The high species density and abundance of Plathelminthes in the salt marsh creek are presumably caused by increased mud accretion and high abundance of diatoms. However, in the course of storm tides much of the mud and detrital particles are washed out of the creek. Storms that flood the salt marshes are more frequent in autumn and winter but rare in summer. Late spring and summer are the periods for mud and detritus accretion, and high diatom abundance. When the salt marsh creek was sampled, these summer conditions were still present. After the first autumnal storm tide in early November, a few samples were collected in the middle and the landward part of the creek. Abundance of both diatoms and Plathelminthes was strongly reduced. Therefore, the rich plathelminth fauna may be special to the summer months without storms tides.

\section{Salt marsh creeks, a small-scale model for the tidal coast?}

Based on the defintion given by Day (1981), the studied salt marsh creek should be called an estuary. Generally, species richness was observed to decrease in a landward direction in estuaries (Wolff, 1983). This was not the case in the plathelminth fauna of the salt marsh creek during this study. Similarly, Warwick \& Gee (1984) describing the Tamar Estuary (Southwest England) stated that nematode and copepode species diversity did not follow the general expectations. Most of our knowledge about estuarine fauna is based on macrobenthos. Possibly meiofauna has quite differnt patterns in estuaries. The plathelminth distribution in North Sea salt marshes is another example: while macrofauna strongly decreases landwards, Plathelminthes are rich in species and abundance is highest in the middle of the marsh (Armonies, 1986, 1987).

It is not known, however, whether the abundance pattern observed in the salt marsh creek in early autumn is present generally or only seasonally. Nevertheless, the present study demonstrates that landward increases in species richness and abundance may occur in estuaries. Small-scale differences in species composition and abundance may coincide with rather slight differences in abiotic factors.

The plathelminth species distribution patterns found in the salt marsh creek strongly resemble those of the adjacent tidal coast. Because of the faunal similarity, such salt marsh creeks might serve as small-scale models for the tidal coast. The supralittoral belt of the salt marsh creek corresponds to the supralittoral of tidal beaches. Most of the plathelminth species found in sublittoral sands north of the island of Sylt are also known from the eulittoral (Wehrenberg \& Reise, 1985). None of the remaining species restricted to the sublittoral of the tidal coast was found in the creek. Therefore, the 'sublittoral' and 'eulittoral' zone of the salt marsh creek together are equivalent to the intertidal of the tidal coast. Presumably, the wider range of environmental factors in the creek is the cause for the absence of strictly sublittoral species.

Since the environmental factors and meiofauna of the salt marsh creek and the adjoining Wadden area are highly similar, these habitats could both be called estuarine. Related to the amount of sea water, fresh water influence is small in both areas, and there seems to be a rather continuous decrease in salinity. On the other hand, sudden changes 
in salinity are found where large rivers enter the sea. Because of the different course of salinity, different reactions of organisms are expected. Small variations of salinity are tolerated better than large-scale fluctuations by more species (Den Hartog, 1964). Therefore, given the wide definition of an estuary by Day (1981), general characteristics of 'estuarine' species cannot be expected. In fact, if all kinds of landward freshwater runoff are considered, the term 'estuarine' becomes a synonym for 'coastal', 'non-marine and non-freshwater', or 'poikilohaline' sensu Dahl (1956).

Acknowledgements. We thank K. Reise for improving this manuscript by critical comments. This study was supported by a grant of the Biologische Anstalt Helgoland.

\section{LITERATURE CITED}

Armonies, W., 1986. Plathelminth abundance in North Sea salt marshes: environmental instability causes hight diversity. - Helgoländer Merresunters. 40, 229-240.

Armonies, W., 1987. Freilebende Plathelminthen in supralitoralen Salzwiesen der Nordsee: Ökologie einer borealen Brackwasser-Lebensgemeinschaft. - Microfauna mar. 3, 81-156.

Armonies, W. \& Hellwig-Armonies, M., 1987. Synoptic patterns of meiofaunal and macrofaunal abundances and specific composition in littoral sediments. - Helgoländer Meeresunters. 41, 83-111.

Ax, P., 1956. Die Einwanderung mariner Elemente der Mikrofauna in das limnische Mesopsammal der Elbe. - Zool. Anz. (Suppl.) 20, 428-435.

Boesch, D. F., 1977. A new look at the zonation of benthos along the estuarine gradient. In: Ecology of marine benthos. Ed. by B. C. Coull. Univ. of South Carolina Press, Columbia, S. C., 245-266.

Bouwman, L A., 1981. The meiofauna of the Ems estuary. - Rep. Wadden Sea Working Group 4, 153-157.

Dahl, E., 1956. Ecological salinity boundaries in poikilohaline waters. - Oikos 7, 1-21.

Day, J. H., 1980. What is an estuary? - S. Afr. J. Sci. 76, 198.

Day, J. H., 1981. The estuarine fauna. In: Estuarine ecology. Ed. by J. H. Day. Balkema, Rotterdam, $147-178$.

Dittmann, S. \& Reise, K., 1985. Assemblage of free-living Plathelminthes on an intertidal mud flat in the North Sea. - Microfauna mar. 2, 95-115.

Gage, J. \& Geekie, A. D., 1973. Community structure of the benthos in Scottish sea-lochs. II. Spatial pattern. - Mar. Biol. 19, 41-53.

Hartog, C. Den, 1964. Typologie des Brackwassers. - Helgoländer wiss. Meeresunters. 10, 377-390.

Hellwig, M., 1987. Ökologie freilebender Plathelminthen im Grenzraum Watt-Salzwiese lenitischer Gezeitenküsten. - Microfauna mar. 3, 157-248.

Reise, K., 1984. Free-living Plathelminthes (Turbellaria) of a marine sand flat: an ecological study. Microfauna mar. 1, 1-62.

Reise, K., 1985. Tidal flat ecology. Springer, Berlin, $191 \mathrm{pp}$.

Riemann, F., 1966. Die Verbreitung der interstitiellen Fauna im Elbe-Aestuar. - Veröff. Inst. Meeresforsch. Bremerhaven (Sonderbd) 2, 117-123.

Sachs, L., 1984. Angewandte Statistik. Springer, Berlin, $552 \mathrm{pp}$.

Sanders, H. L., 1968. Marine benthic diversity: a comparative study. - Am. Nat. 102, 243-282.

Warwick, R. M. \& Gee, J. M., 1984. Community structure of estuarine meiobenthos. - Mar. Ecol. Prog. Ser. 18, 97-111.

Wehrenberg, C. \& Reise, K., 1985. Artenspektrum und Abundanz freilebender Plathelminthes in sublitoralen Sänden der Nordsee bei Sylt. - Microfauna mar. 2, 163-180.

Wolff, W. J., 1983. Estuarine benthos. In: Estuaries and enclosed seas. Ed. by B. H. Ketchum. Elsevier, Amsterdam, 151-182. 